\title{
En Az Beş Yıllık Olan Depolanmış Atık Ofis Kâğıtlarının Geri Dönüşüm Olanaklarının Araştırılması
}

\author{
Investigation of Recycling Possibilities of Stacked Waste Office Paper for at Least Five \\ Years
}

\section{Selim KARAHAN*}

Gümüşhane Üniversitesi, Kürtün Meslek Yüksekokulu, Ormancllı Bölümü, 29810, Gümüşhane

• Geliş tarihi / Received: 18.08.2019 • Düzeltilerek geliş tarihi / Received in revised form: 27.01.2020 • Kabul tarihi / Accepted: 01.02 .2020

\begin{abstract}
$\ddot{O} z$
Bu çalışmada, arşiv niteliğindeki (en az 5 yıl depolanmış) ofis kâğıtlarının geri dönüşüm olanakları araştırılmaktadır. Bu kâğıtların imhaları çoğunlukla yakılarak yapılmaktadır. Bu ise tonlarca kâğıt hammaddesini yok etmektir. Bu kâğıtlar basit bir hamurlaştırma veya küçük parçalara ayırma işlemi ile geri dönüşüme sunulabilir. $\mathrm{Bu}$ ise ülke ekonomisine büyük katkı sağlayacaktır. Çalışmada ayrıca bu kâğıtların fiziksel ve optik özelliklerine bakılmıştır. Bu kâğıtlar depolandığı yerlerde gerek fiziki koşullardan (nem, sıcaklık) gerekse mantarlar ve böceklerden dolayı lif dirençlerinde ve parlaklıklarında kayıplar muhtemeldir. Ayrıca bu kâğıtlardan mürekkebi çıkarırken liflerin parlaklık ve direncinde de kayıplar meydana gelecektir. Çalışmada bu kayıpların ne kadar olduğu ise araştırılmıştır. Bu sayede kayıpları telafi etmek için bir takım uygulamalar da beraberinde yapılmıştır. Bu işlemler ile tonlarca atık kâğıt hammaddesine kavuşulacak ve istenilen kaliteye yakın yeni atık beyaz ofis kâğıtların üretilmelerine olanak sağlanacaktır.
\end{abstract}

Anahtar kelimeler: Lazer Baskı, Mürekkep Giderme, Ofis Kâğıdı, Yüksek Kesafetli Hamurlaştırıcı, Yüzdürme

\begin{abstract}
In this study, investigates recycling possibilities of office paper in archive form (stored for at least 5 years). These papers are mostly made by burning. This is to destroy tons of paper raw materials. These papers may be presented with a simple pulping or recycling with small fractionation. This will contribute greatly to the country's economy. The study will also look at the physical and optical properties of these papers. These papers are likely to lose fiber resistance and brightness due to the physical conditions (humidity, temperature) and the mushrooms and insects. In addition, loss of the shine and resistance of the fibers will come to the fore when the ink is removed from these papers. How much of these losses are in the study will be investigated. This will be done in conjunction with a number of applications to compensate for losses. With these operations, tons of waste paper raw materials will be obtained and new waste white office paper will be produced with the desired quality.
\end{abstract}

Keywords: Laser Printing, Deinking, Office Paper, High Consistency Pulping, Flotation

* Selim KARAHAN; selimkarahan@msn.com, Tel: (0456) 2331018 (dahili: 3402), orcid.org/0000-0002-8499-2427 


\section{Giriş}

Ağaçların gerek doğada yaşayan canlılar için bir barınma ve gerekse de oksijen üretimi açısından faydası çok önemlidir. Çalışmada kâğıt hammadde kaynağı olarak ağaçların kesilmesini azaltıp elimizdeki kâğıt hammadde kaynaklarını kullanma olanakları araştırılmıştır. Bu sayede ülke hammadde yönünden dışa bağımlılığı azalacak ve ülke ekonomisi kazanç sağlayacaktır. Ülkemizdeki kâğıt sektörü açısından uluslararası pazarlarda devamını sağlayabilmesi için rekabet gücünü yükseltmesi için iyi nitelikli, ekonomik ve yeterli miktarlarda lifsel hammadde kaynaklarının sürdürülebilir olması gerekmektedir. Oduna esaslı lifsel hammadde üretiminin ise hem ekonomik yönden hem de teknoloji beraberinde getirmektedir. Ülkemizde ise kâğıt tüketimi her geçen gün fazlalaşmaktadır. Ekonomik ve kaliteli hammadde çözümü için geri dönüşüm büyük önem arz etmektedir. Bundan dolayı beş yılı aşkın süre bekleyen atık ofis kâğıtlarının değerlendirilme olanakları araştırılmıştır (Karahan vd., 2015a; Karahan ve Karademir, 2019).

Atık kâğıtların geri dönüşümündeki esas amaç; çok farklı kaynaklardan gelen ve homojen bir yapı sergilemeyen atık kâğıt hammaddesini istenilen türdeki kâğıt üretimi için uygun özellikte olan temiz ve homojen bir hamura çevirmektir (Kırc1, 2006; Karahan, 2017a). Atık kâğıtların üretim yöntemleri farklı olup, atık kâğı balyaları çok çeşitli dolgu maddeleri ve çok farklı kimyasal katk1 maddelerini bünyesinde barındırabilirler. Buna ise kâğıt hammaddesinde lif kalitesini, lifin işlenebilme özelliğini ve son ürününün veriminde, kalitesinde ve maliyetinde değişiklikler yapabilir (Karademir ve İmamoğlu, 2001; Karahan vd., 2015a; Karahan, 2017b; Karahan ve Karademir, 2019).

Lifsel hammadde kaynağı olarak kullanılan atık kâğıtlar daha çok işyerleri ve okullarda kullanılan fotokopi, defter, yazıcı kâğıtları gibi veya matbaa ve kesim tesislerinin mekanik hamur oranı düşük beyaz kâğıt içerikli atık veya artıkları, yüksek optik niteliklerinin istendiği temizlik ve yazı kâğıdı üretiminde kullanılan ikincil lif kaynaklarıdır (İmamoğlu, 2002). Atıl durumdaki ürün değerlendirildiği zaman ürünün kalite değerinin de artırılması sağlanacaktır. Bu sayede hem hammadde bulma hem de ülke ekonomisine katkı sağlama açısından faydalı olacaktır. Ticari olarak bu işlem her zaman sulu ortamda yapılmıştır, ancak özel durumlarda bir başka çözücü madde kullanılmaması için bir sebep yoktur (Heise vd., 1996).

Mürekkep giderme işlemi en basit ifadesiyle atık kâğıtlardan lifsel olmayan yabancı maddelerin uzaklaştırılmasıdır. Bu işlem ise hamurlaştırma ve yüzdürme işlemlerinden oluşmaktadır (Kırc1, 2000; Karahan vd., 2015a). Mürekkep giderme işleminde, atık kâğıtların bünyesindeki mürekkep parçacıklarını en yüksek seviyede uzaklaştırıldıktan sonra temiz lifleri tekrar geri kazanıma katılması arzu edilmektedir (Kıran vd., 2006; Karahan vd., 2015b).

\section{Deneysel Çalışma}

$\mathrm{Bu}$ çalışmada, beyaz A4 ofis kâğıtları üzerine siyah lazer baskılar yapılmış ve en az 5 yıl bir süre ile kullanılmadan bekletilmiştir. Araştırmada standart yüzdürme metoduna göre mürekkep giderme işlemi yapılmıştır. $\mathrm{Bu}$ işlemde ise, sodyum hidroksit, hidrojen peroksit, sodyum silikat, oleik asit ve kalsiyum klorür'de Ingede 1 (Ingede, 2007a), 2 (Ingede, 2007b) ve 11 (Ingede, 2007c) metotlarına göre kullanılmıştır (Karahan, 2017b).

Çalışmada yeni atık ofis kâğıtları (1 sene) ve eski ofis kâğıtlarına (5 sene) iki farklı işlem uygulanmıştır. Önce eski ve yeni atık ofis kâğıttları farklı oranlarda karıştırılmıştır. Birinci işlemde bu karışım hamurlaştırıcı ile belirlenen parametrelerde hamurlaştırma işlemi yapılmıştır. İkinci işlemde ise bu karışıma belirlenen oranlarda kimyasal ilavesi yapılmıştır.

Kâğıt hamur karışımı hamurlaştırıcı ile belirlenen oranlarda yapılmıştır. Bu işlemlerin sonrasında ise işlem görmüş olan atık kâğıt hamuru, yüzdürme esaslı mürekkep giderme işlemine alınarak mürekkeplerinden tamamen uzaklaştırılmaya çalışılmıştır (Karahan, 2017b). Çalışma sonunda ise elde edinilen test kâğıtları üzerinde fiziksel mukavemet ve optik testler yapılmıştır. Tablo 1'de kimyasallı ve kimyasalsız işlemlere ait hamur karışım oranları verilmiştir.

Ofis kâğıtları ingede standardına uygun olacak biçimde $2 \times 2 \mathrm{~cm}$ boyutlarında el ile parçalara ayrılmıştır. Parçalanmış kağıtlar daha sonra ağzı kapatılabilen polietilen poşetler içerisinde 1 şı ve sicaklıktan korunarak depolanmıştır. Daha sonra ise baskı yapılan ofis kâğıtlarına standart Ingede metoduna göre hamurlaştırma işlemleri yapılmıştır. Ofis kâğıt rutubetleri ortalama \%3 olarak bulunmuştur. 
Tablo 1. Kimyasallı ve kimyasalsız işlemlere ait hamur karışım oranları

\begin{tabular}{cccccc} 
Hamur Tipleri & \multicolumn{6}{c}{ Hamur Karışım Oranları (\%) } \\
& $\mathbf{0}$ & $\mathbf{2 5}$ & $\mathbf{5 0}$ & $\mathbf{7 5}$ & $\mathbf{1 0 0}$ \\
\hline YO & EO & -- & -- & -- & YO \\
\hline EO & YO & -- & -- & -- & EO \\
\hline YB & -- & -- & -- & -- & YB \\
\hline EB & -- & -- & -- & -- & EB \\
\hline YB-EB-25 & -- & EB & -- & YB & -- \\
\hline YB-EB-50 & -- & -- & YB-EB & -- & -- \\
\hline YB-EB-75 & -- & YB & -- & EB & -- \\
\hline
\end{tabular}

Hamurlaştırma işlemleri iki kademede yapılmıştır. Her kademede $103.11 \mathrm{~g}$ (Tam kuru) hamur kullanılmıştır. Hamurlaştırma işlemleri için Hobart tipi hamurlaştırıcı cihaz kullanılmıştır. Bu cihaz ile belirlenen devir hizları ve sürelerinde (Tablo 2) hamurlaştırma işlemleri yapılmıştır (Karahan, 2017c).

Hamurlaştırma işleminde kullanılan kimyasal maddeler, Ingede standardında belirlenen ölçülere göre sabit alınmıştır. Ingede metodunda önerilen kimyasallardan sodyum hidroksit \%0.6; hidrojen peroksit $\% 0.7$; sodyum silikat $\% 1.8$ ve oleik asit $\% 0.8$ olarak kullanılmıştır. Ofis kâğıtları üzerindeki mürekkebin şişirilerek liflerden ayrılması için sodyum hidroksit, kâğıtların sararmadan beyazlatılması için hidrojen peroksit, lifler üzerindeki mürekkep parçacıklarının gevşemesi ve tekrardan liflerin üzerine birikmesini engellemek için sodyum silikat ve liflerden sökülen mürekkep parçacıklarını yakalayıp yüzeye taşınması işlemleri içinde oleik asit kullanılmıştır (Kırc1, 2000).

Tablo 2. Hamurlaştırma ile ilgili veriler

\begin{tabular}{cccccc}
\hline İşlem & $\begin{array}{c}\text { Devir } \\
(\text { devir/dk) }\end{array}$ & $\begin{array}{c}\text { Kesafet } \\
(\%)\end{array}$ & $\begin{array}{c}\text { Süre } \\
(\mathbf{d k})\end{array}$ & $\begin{array}{c}\text { Kağıt \& Hamur } \\
\text { miktarı } \\
(\mathbf{g})\end{array}$ & $\begin{array}{c}\text { Kimyasal } \\
\text { Madde }\end{array}$ \\
\hline Ön bekletme (Islatma) & --- & 15 & 5 & 103.11 & - \\
\hline 1. Hamurlaş̧ırma & $55 ; 85 ; 150$ & 15 & $9(3 ; 3 ; 3)$ & 103.11 & + \\
\hline 2. Hamurlaştırma & 150 & 14 & 9 & 103.11 & - \\
\hline
\end{tabular}

Atık kâğıt hamurlarından sulu süspansiyon elde edilmesinde standart hammadde hazırlama metoduna göre yapılmıştır. Konsantrasyonu bilinen hamur süspansiyonlarından standart 80 $\mathrm{g} / \mathrm{m}^{2}$ gramajında laboratuvar tipi test kâğıtları üretilmiştir. El kâğıtları yapımında Standard British Handsheet Former cihazinda belirlenen standarda göre el kâğıtları yapılmış ve bu kâğıtların optik analizleri ise Elrepho marka Optik test cihazı ile yapılmışıtır. Elde edilen bu deneme kâğıtlarına aşağıda belirtilen testler uygulanmıştır.

- El kâğıdı oluşturma (Tappi Test Metodu T 205, 1992).

- Rutubet belirleme (Tappi Test Metodu T 412, 1992).
- Patlama direnci belirleme (Tappi Test Metodu T 403, 1992).

- Yırtılma dayanımı (Tappi Test Metodu T 414, 1992).

- Hava geçirgenliği belirleme (Tappi Test Metodu T 547, 1992).

- Kopma dayanımı (Tappi Test Metodu T 404, 1992).

- Gramaj belirleme (Uluslararası Standart DIS 536, 1993).

- Beyazlık belirleme (Uluslararası Standart DIS 11476, 1997).

- Opaklık belirleme (Uluslararası Standart DIS 2471, 1997). 
Tablo 1'de belirtilen hamur tiplerinin değerleri;

- YO : Yeni baskısız ofis kağıdı (\%100)

- EO : Eski baskısız ofis kağıdı (\%100)

- YB : Yeni baskılı ofis kağıdı (\%100)

- EB : Eski baskılı ofis kağıdı (\%100)

- YB-EB-25 : Yeni baskılı ofis kağıt oranı (\%75) - Eski baskılı ofis kağıt oranı (\%25)

- YB-EB-50 : Yeni bask1lı ofis kağıt oranı (\%50) - Eski baskılı ofis kağıt oranı (\%50)

- YB-EB-75 : Yeni baskılı ofis kağıt oranı (\%25) - Eski baskılı ofis kağıt oranı $(\% 75)$ değerlerini belirtmektedir.

\section{Bulgular ve Tartışma}

Yapılan çalışmalar sonucu üretilen test malzemelerine ait yapılan testlerde aşağıdaki şekiller elde edilmiştir.
Belirlenen oranlarda hazırlanan eski ve yeni ofis kâğıt karışımları ile (beyaz ve baskı1ı ofis kâğıt) bu ofis kağıt karışımları üzerine yine belirlenen oranlarda kimyasal katılımı sonucundaki çekme indisi (Şekil 1) ve patlama indisi (Şekil 2) değerlerinin her ikisinde de kimyasall ve kimyasalsız işlemlerdeki eski ve yeni beyaz ofis kağıtları üzerinde bir değişikliğe neden olmamıştır. Baskılı ofis kâğıtlarında ise hem kimyasallı hem de kimyasalsız işlemlerde çekme indisi ve patlama indisi değerlerinde bir artışa neden olurken, Kimyasallı işlemlerdeki çekme indisi ve patlama indisi değerlerinde ise daha fazla bir artışa sebep olmuştur. Muhtemelen bu durum kimyasallı işlemde mürekkebin daha fazla uzaklaştırılması ile liflerin birbirine daha iyi tutunduğu söylenebilir. Çekme indisi ve patlama indisi değerinde en fazla artış yeni baskılı ofis kâğıtlarında (YB) iken en az artış ise eski baskılı ofis kâğıtlarında (EB) gözlemlenmiştir. Muhtemelen bu durum lif yapısının zamanla daha fazla deforme olması kaynaklandığı söylenebilir. Eski ofis kâğıtlarına belirlenen oranlarda yeni ofis kâğıt karışımı eklenmesine paralel olarak ta çekme indisi ve patlama indisi değerlerinde de kademeli olarak bir artış gözlemlenmiştir.



Şekil 1. Eski ve yeni ofis kâğıt karışımları üzerinde uygulanan kimyasallı ve kimyasalsız işlemlerin çekme indisi üzerine etkisi

Belirlenen oranlarda hazırlanan eski ve yeni ofis kâğıt karışımları ile (beyaz ve baskılı ofis kâğıt) bu ofis kâğıt karışımları üzerine yine belirlenen oranlarda kimyasal katılımı sonucundaki yırtılma indisi (Şekil 3) üzerindeki etkisinde, genel olarak eski ofis kâğıtlarının yırtılma indis değerleri daha yüksek çıkmıştır. Yırtılma indis değeri ölçülen bir kuvvetten ziyade belirli bir uzunluk boyunca kâğıdı yırtmak için yapılan iştir (Eroğlu ve Usta, 2004). Muhtemelen bu durum ise ofis kâğıtlarının zamanla liflerin deforme olmasi ve tekrar liflendirilmesi ile de eski ofis kâğıtlarının yeni ofis kâğıtlarından daha fazla lif boylarının kısalması ile daha yoğun bir yapı oluşmuş ve lifler kendi aralarında daha fazla bağ kurmuş olabilir. 


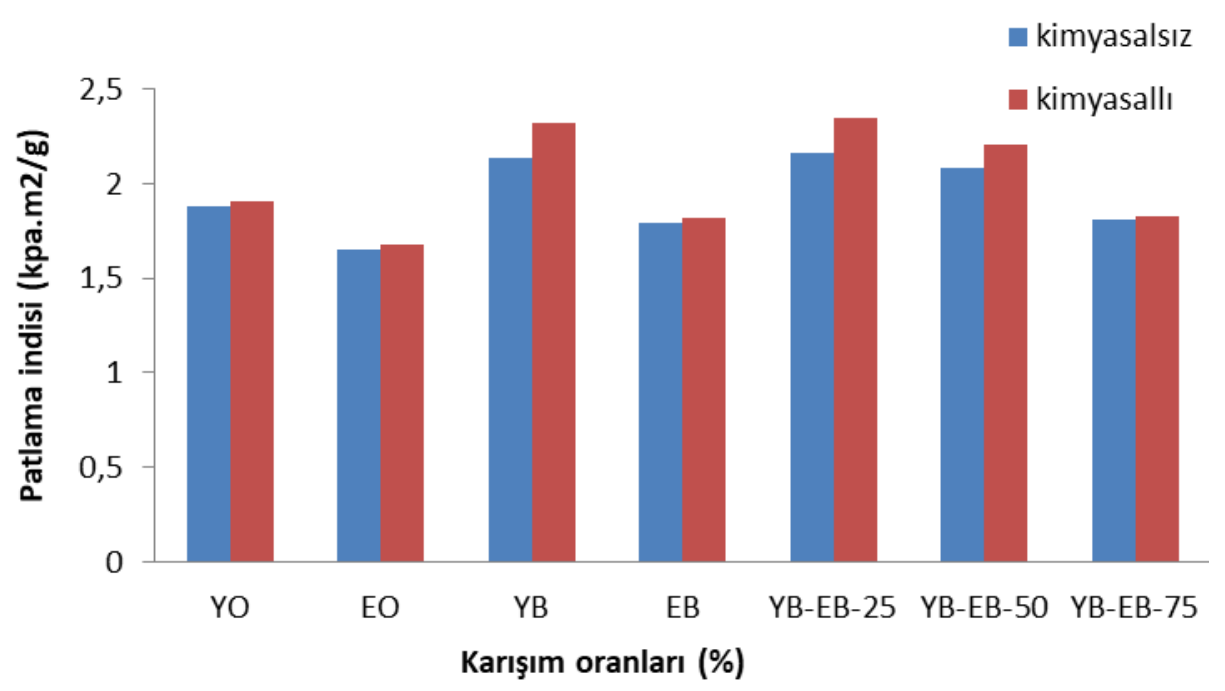

Şekil 2. Eski ve yeni ofis kâğıt karışımları üzerinde uygulanan kimyasallı ve kimyasalsız işlemlerin patlama indisi üzerine etkisi



Şekil 3. Eski ve yeni ofis kâğıt karışımları üzerinde uygulanan kimyasallı ve kimyasalsız işlemlerin yırtılma indisi üzerine etkisi

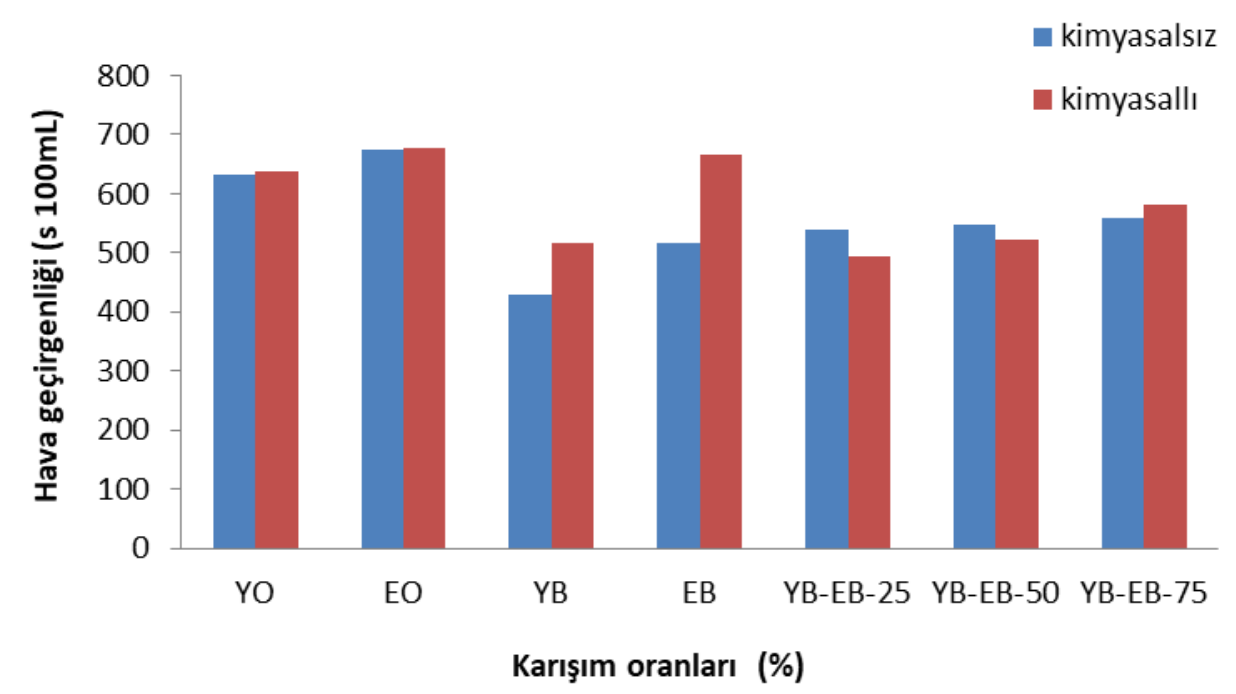

Şekil 4. Eski ve yeni ofis kâğıt karışımları üzerinde uygulanan kimyasallı ve kimyasalsız işlemlerin hava geçirgenliği üzerine etkisi 
Belirlenen oranlarda hazırlanan eski ve yeni ofis kâğıt karışımları ile (beyaz ve baskılı ofis kâğıt) bu ofis kâğıt karışımları üzerine yine belirlenen oranlarda kimyasal katılımı sonucundaki hava geçirgenliği (Şekil 4) üzerindeki etkisinde genel olarak eski ofis kâğıtlarının hava geçirgenliği değerleri daha yüksek çıkmıştır. Eski ve yeni ofis karışımında eski ofis kâğıt oranlarının artmasına paralel olarak ta hava geçirgenliği değerlerinde de kademeli olarak bir artış gözlemlenmiştir. Muhtemelen bu durum eski ofis kâğıtlarında zamanla kırıntı miktarının arması ile hazırlanan karışım materyali de daha yoğun bir yap1 kazanmıştır. Kimyasallı işlemlerde ise mürekkebin daha fazla uzaklaştırılması ile hem kırıntı miktarı artmış hem de lifler daha fazla birbirine yaklaşmış ve daha yoğun bir yapı oluşturmuş olabilir.
Belirlenen oranlarda hazırlanan eski ve yeni ofis kâğıt karışımları ile (beyaz ve baskı1ı ofis kâğıt) bu ofis kâğıt karışımları üzerine yine belirlenen oranlarda kimyasal katılımı sonucundaki beyazlık (Şekil 5) üzerindeki etkisinde genel olarak eski ofis kağıtlarının beyazlık değerleri daha düşük çıkmıştır. Eski ve yeni ofis karışımında eski ofis kâğıt oranlarının artmasına paralel olarak ta beyazlık değerlerinde de kademeli olarak bir azalış gözlemlenmiştir. Muhtemelen bu durum eski ofis kâğıtlarında zamanla kırıntı miktarının arması ile daha fazla 1 şı̆̆ 1 absorbe etmesi ve liflerin zamanla eskimeye uğramasından dolayı parlaklığının azaldığı söylenebilir. Kimyasallı işlemlerde beyazlığının daha fazla olması, mürekkebin daha fazla uzaklaştırılması ile 1şı̆̆ emen toner miktarının azalmış olması; buna bağlı olarak gelen 1 şı ğı daha fazla yansıtması ile açıklanabilir.



Şekil 5. Eski ve yeni ofis kâğıt karışımları üzerinde uygulanan kimyasallı ve kimyasalsız işlemlerin beyazlık üzerine etkisi

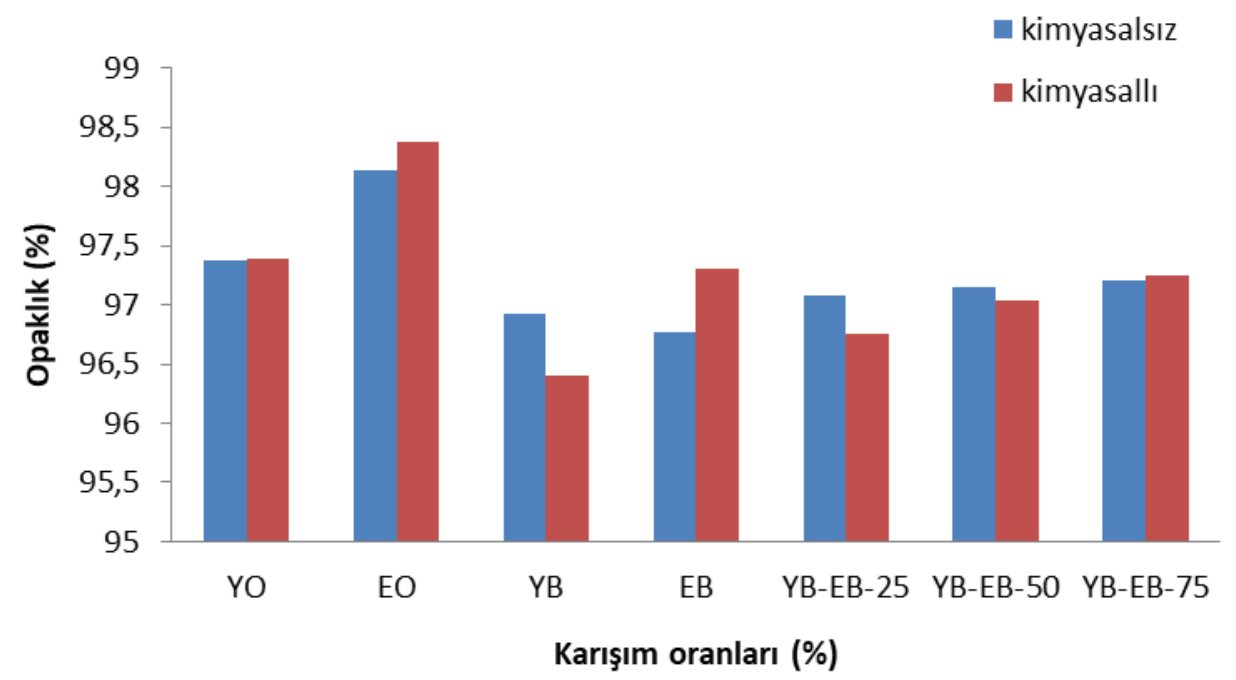

Şekil 6. Eski ve yeni ofis kâğıt karışımları üzerinde uygulanan kimyasallı ve kimyasalsız işlemlerin opaklık üzerine etkisi 
Belirlenen oranlarda hazırlanan eski ve yeni ofis kâğıt karışımları ile (beyaz ve baskılı ofis kâğıt) bu ofis kâğıt karışımları üzerine yine belirlenen oranlarda kimyasal katılımı sonucundaki opaklık (Şekil 6) üzerindeki etkisinde genel olarak eski ofis kâğıtlarının opaklık değerleri daha yüksek çıkmıştır. Eski ve yeni ofis karışımında eski ofis kâğıt oranlarının artmasına paralel olarak ta opaklık değerlerinde de kademeli olarak bir artış gözlemlenmiştir. Muhtemelen bu durum eski ofis kâğıtlarında zamanla kırıntı miktarının arması ile hazırlanan karışım materyali de daha yoğun bir yapı kazanmıştır. $\mathrm{Bu}$ ise gelen 1şı̆̆ın materyalin diğer tarafina geçişini zorlaştırmıştır. Kimyasallı işlemlerde ise mürekkebin daha fazla uzaklaştırılması ile hem kırıntı miktarı artmış hem de lifler daha fazla birbirine yaklaşmış ve daha yoğun bir yapı oluşturmuş olabilir.

\section{Sonuçlar}

Test sonuçlarına genel olarak bakıldığında; eski ofis kâğıtları ile yeni ofis kâğıt karışımlarında, karışıma eklenen yeni ofis kâğıt oranının artmasına paralel olarak elde edilen test kâğıtlarının fiziksel ve optik özelliklerinde de bazı değişiklikler meydana gelmiştir. Aynı işleme kimyasal eklenmesi ile de fiziksel ve optik işlemde meydana gelen değişiklikler daha belirgin bir durum gözlenmiş̧ir. Eski ofis kâğıt karışımına yeni ofis kâğıtları belli bir oran ile artırılarak eklenmesi ile elde edilen test kâğıtlarının fiziksel direnç özeliklerinde (çekme indisi, patlama indisi) ve optik özelliklerinde (beyazlık) iyileşmeler meydana gelmiştir. Fakat bu iyileşmeler yeni ofis kâğıdının üst sınırına ulaşamamıştır. Eski ofis kâğıtlarının tekrar hamurlaştırılması ile yırtılma indisi, hava geçirgenliği ve opaklık değerleri, yeni ofis kâğıdındaki bu değerlerin üzerine çıkmıştır. $\mathrm{Bu}$ ise eski ofis kâğıtlarının daha yoğun bir yapı kazandığını göstermektedir. Eski ofis kâğıtlarının diğer fiziksel değerleri (çekme indisi, patlama indisi) ve optik değeri (beyazlık) düşük çıktığı için genel olarak düşünüldüğünde yeni ofis kâğıdının fiziksel (çekme indis, patlama indis) ve optik değerlerinin (beyazlık) altında kalmaktadır. $\mathrm{Bu}$ durum olumsuz gibi görünse de eski ofis kâğıtlarına belli oranlarda artırılarak yeni ofis kâğıtları eklenmesi suretiyle de bu durum olumsuzluğun da da görünen bir iyileşme yoluna gidilmiştir. Atık kâğıt işleyen fabrikalarda eski ofis kâğıtlarını kullanırken, karışım için yeni ofis kâğıdı bulunmasında sıkıntı çekiliyorsa bu eski ofis kâğıt hamur süspansiyonuna mukavemet artırıcı ve ağartıcı kimyasalların eklenmesi veya bu kimyasalların dozajının biraz artırılması suretiyle de elde ettikleri test kâğıdının test değerlerini artırma yoluna gidebilirler.

\section{Teşekkür}

$\mathrm{Bu}$ çalışma, Gümüşhane Üniversitesi Bilimsel Araştırma Projeleri (GÜBAP) Koordinatörlü tarafindan desteklenmiştir. Proje No: 16.B0822.02.01

\section{Kaynaklar}

DIS 536, 1993. Kâğıt ve Karton için Gramaj Belirleme, Uluslararası Standart verisi.

DIS 11476, 1997. Kâğıt ve Karton için Beyazlık Belirleme, Uluslararası Standart verisi.

DIS 2471, 1997. Kâğıt ve Karton için Opaklık Belirleme, Uluslararası Standart verisi.

Eroğlu, H. ve Usta, M. 2004. Kâğıt ve Karton Üretim Teknolojisi, KTÜ, Trabzon.

Heise, O.U., Unwin, J.P., Klungness, J.H., Fineran, W.G. and Syekes, J.R.M., 1996. Abubakr, S., Industrial Scaleup of Enzyme-Enhanced Deinking of Nonimpact Printed Toners. TAPPI Journal, 79 (3), 207-212.

Ingede Test Metodu 1, 2007a. Optik Özelliklerin Ölçümü için Mürekkebi Giderilmiş Hamurdan Test Kâğıdı Hazırlama, Uluslararası Mürekkep Giderme Sanayi Kurumu verileri.

Ingede Test Metodu 2, 2007b. Hamurun Optik Özelliklerinin Ölçümü ve Mürekkep Gidermedeki Süzüntü İşlemleri, Uluslararası Mürekkep Giderme Sanayi Kurumu verileri.

Ingede Test Metodu 11, 2007c. Baskılı Ürünün Geri Dönüşülebilirliği, Uluslararası Mürekkep Giderme Sanayi Kurumu verileri.

İmamoğlu, S., 2002. Atık Kâğı Hamurlarının Formamaidin Sülfinik Asit (FAS) ile Ağartılması. Doktora Tezi, İstanbul Üniversitesi Fen Bilimleri Enstitüsü. İstanbul.

Karahan, S., 2017a. Atık Ofis Kâğıtlanı Üzerinde Yapılan Mürekkep Giderme İşleminin Hamur Verimi ve Atık Çamur Üzerine Etkileri. Düzce Üniversitesi Bilim ve Teknoloji Dergisi, 5 (1), 67-75.

Karahan, S., 2017b. Mürekkep Giderme İşleminin Ofis Kâğıtları Üzerindeki Fiziksel Direnç Özellikleri Üzerine Etkisi. Düzce Üniversitesi Bilim ve Teknoloji Dergisi, 5 (1), 76-83.

Karahan, S., 2017c. Kâğıdın Optik Özellikler Üzerine Mürekkep Giderme İşlemi ile Farklı 
Uygulamaların Etkileri. Düzce Üniversitesi Bilim ve Teknoloji Dergisi, 5 (1), 146-160.

Karahan, S. ve Karademir, A., 2019. Mürekkep Giderme İşleminin Farklı Atık Kâğıtlar Üzerindeki Etkisi. Düzce Üniversitesi Bilim ve Teknoloji Dergisi, 7 (1), 15-24.

Karahan, S., Karademir, A. ve Güvendi, E., 2015a. Ofis Kâğıtları Üzerindeki Mürekkep Giderme İşleminin Taramalı Elektron Mikroskobu ile Analizi. Düzce Üniversitesi Bilim ve Teknoloji Dergisi, 3 (1), 299-314.

Karahan, S., Karademir, A. ve Güvendi, E., 2015b. Mürekkep Giderme İşleminin Lazer Baskılı Ofis Kâğıtlarındaki Organik ve Anorganik Madde Miktarları Üzerine Etkileri. Düzce Üniversitesi Bilim ve Teknoloji Dergisi, 3 (1), 241-250.

Karademir, A. ve İmamoğlu, S., 2001. Kağıtların Doğal Yaşlanmasına Bağlı Önemli Değredasyon Reaksiyonları, Fen ve Mühendislik Dergisi , 4 (2), 98-108.

Kırcı, H., 2000. Atık Kâğıt Geri Kazanma Teknolojisi, KTÜ, Trabzon.
Kırcı, H., 2006. Kâğıt Hamuru Endüstrisi Ders Notları, KTÜ, Trabzon.

Kıran, Ö.E., Çömlekçioğlu, U. ve Dostbil, N., 2006. Bazı Mikrobiyal Enzimler ve Endüstrideki Kullanım Alanları. KSU Fen ve Mühendislik Dergisi, 9, 12-19.

Tappi T 205 sp-06, 1992. Hamurun fiziksel testi için el kâğıdı oluşturma, Tappi Test Metodu verisi.

Tappi T 412-om-90, 1992. Kâğıt ve karton için rutubet belirleme, Tappi Test Metodu verisi.

Tappi T 403 om-91, 1992. Kâğıt için patlama direnci belirleme, Tappi Test Metodu verisi.

Tappi T 414-om-04, 1992. Kâğıdın iç yırtılma dayanımı, Tappi Test Metodu verisi.

Tappi T 547 om-12, 1992. Kâğıt ve karton için hava geçirgenliği belirleme, Tappi Test Metodu verisi.

Tappi T 404 om-87, 1992. Kâğıt ve karton için uzaması ve kopma dayanımı, Tappi Test Metodu verisi. 